\title{
Postoperative Alcaligenes xylosoxidans endophthalmitis: report of two cases
}

\author{
Endoftalmite pós-operatória causada por Alcaligenes xylosoxidans: \\ relato de dois casos
}

\author{
Alejandra de-la-Torre ${ }^{1}$ \\ Christian Adrián López-Castillo \\ Javier Andrés Bernal-Urrego ${ }^{3}$ \\ Juan Pablo Sinisterra-Pava ${ }^{4}$ \\ Jorge Enrique Gómez-Marín ${ }^{5}$
}

Trabalho realizado na Universidad del Quindío. Armenia - Colombia.

${ }^{1}$ Medical Doctor (MD). Grupo de Estudio en Parasitología Molecular (GEPAMOL). Universidad del Quindío. Armenia - Colombia.

Medical School Student. GEPAMOL. Universidad del Quindío. Armenia - Colombia.

3 Medical Doctor (MD). Clínica Oftalmológica CIAO. Armenia - Colombia.

${ }^{4}$ Medical Doctor (MD). Instituto Para Niños Ciegos Y Sordos Del Valle Del Cauca. Cali - Colombia.

${ }^{5}$ Medical Doctor (MD). MSc. PhD. GEPAMOL. Universidad del Quindío. Armenia - Colombia.

Address to correspondence: Alejandra de-la-Torre. Grupo de Estudio en Parasitología Molecular (GEPAMOL), Centro de Investigaciones Biomédicas, Universidad del Quindío. Cra 15 Calle 12N - Armenia - Colombia. E-mail: alejadelatorre@yahoo.com

Recebido para publicação em 30.01.2007

Última versão recebida em 06.08 .2007

Aprovação em 19.09.2007

\begin{tabular}{l} 
ABSTRACT \\
\hline We report two cases of postoperative Alcaligenes xylosoxidans endo- \\
phthalmitis. A 78-year-old woman in good general health developed $A$. \\
xylosoxidans endophthalmitis one month after an uncomplicated pha- \\
coemulsification procedure with posterior chamber intraocular lens. It \\
was performed on her left eye, at another institution. Removal of the \\
intraocular lens and capsule was performed because of recurrent in- \\
flammation after vitrectomy and intravitreal antibiotic injections. Her \\
son, a 55-year-old man, developed A. xylosoxidans endophthalmitis in \\
his left eye, two months after an uncomplicated phacoemulsification \\
procedure with posterior chamber intraocular lens (it also was perfor- \\
med by the same surgeon). He also required vitrectomy with removal of \\
the intraocular lens and capsule because of persistent disease. A. xyloso- \\
xidans can cause chronic low-grade and progressive endophthalmitis \\
after cataract extraction that is often resistant to corrective antibiotic \\
therapy. This kind of case is rare. There have been only previously \\
reported seven cases worldwide to the best of our knowledge.
\end{tabular}

Keywords: Alcaligenes/isolation \& purification; Cataract extraction/adverse effects; Endophthalmitis/microbiology; Eye infections, bacterial/microbiology; Lens implantation, intraocular; Reoperation; Vitrectomy; Vitreous body/microbiology; Adult; Aged; Female; Male; Case reports [publication type]

\section{INTRODUCTION}

One of the most important complications of cataract surgery is intraocular infection or endophthalmitis. Chronic postoperative endophtalmitis is frequently caused by Propionibacterium acnes ${ }^{(1)}$. In general, the worldwide incidence is between 0.10 and $0.18 \%$, according to the data published by Soriano and Nishi in the $2005^{(2)}$. Alcaligenes xylosoxidans is a gram-negative rod that has been rarely reported to cause postoperative endophthalmitis. In these cases the disease is generally of chronic evolution and low virulence ${ }^{(3-}$ ${ }^{8)}$, in opposition to the other of gram-negative rods.

\section{CASE REPORTS}

\section{Case 1}

An otherwise healthy 78-year-old woman underwent phacoemulsification and posterior chamber intraocular lens implantation in the left eye. This operation was performed at another institution. One month after the operation she experienced pain and blurred vision. The patient was treated 
with topical dexamethasone and tobramycin with clinical improvement for three months. Her best-corrected visual acuity (BCVA) was 20/50. Four months after the operation, she developed posterior capsule opacification and underwent yag laser capsulotomy. After this procedure, she developed low-grade iridociclitis without improvement of visual acuity. The vitreous was clear, and no retinal abnormalities could be detected. She was maintained on topical prednisone and diclofenac for two months and improved clinically; her BCVA was 20/25. By postoperative month twelve, she developed recurrent pain, red eye, loss of vision, her visual acuity suddenly decreased to hand motions, and severe vitritis was observed. She underwent pars plana vitrectomy and intravitreal vancomycin was injected. Topical ciprofloxacin, atropine, and prednisolone acetate $1 \%$ were started. Cultures of the vitreous grew Alcaligenes xylosoxidans, a motile gram-negative rod, sensitive to ampicillinsulbactam, trimethoprim/sulfametoxazol, imipenem and piperacillin, and resistant to gentamicin, ciprofloxacin, tetracycline, and cloramphenicol. She was treated with oral trimetoprim/sulfamethoxazol, without complete resolution of the inflammatory reaction. She was subsequently referred to our center. Upon examination, her BCVA was 20/100 in the left eye. There were $2+$ anterior chamber cells and mild inflammation of the anterior vitreous cavity. Vancomycin and amikacin were injected intravitreally. As the inflammation recurred three weeks after the treatment with intraocular antibiotics, we performed explantation of the intraocular lens and removal of the lens capsule (Figure 1). After surgery, the inflammation resolved in a period of three weeks and did not recur. The patient's best-corrected aphakic visual acuity was $20 / 80$, because of cystoid macular edema.

\section{Case 2}

The second case is a 55-year-old man who complained of pain, red eye, and blurred vision, two months after uncomplicated phacoemulsification and posterior chamber intrao-

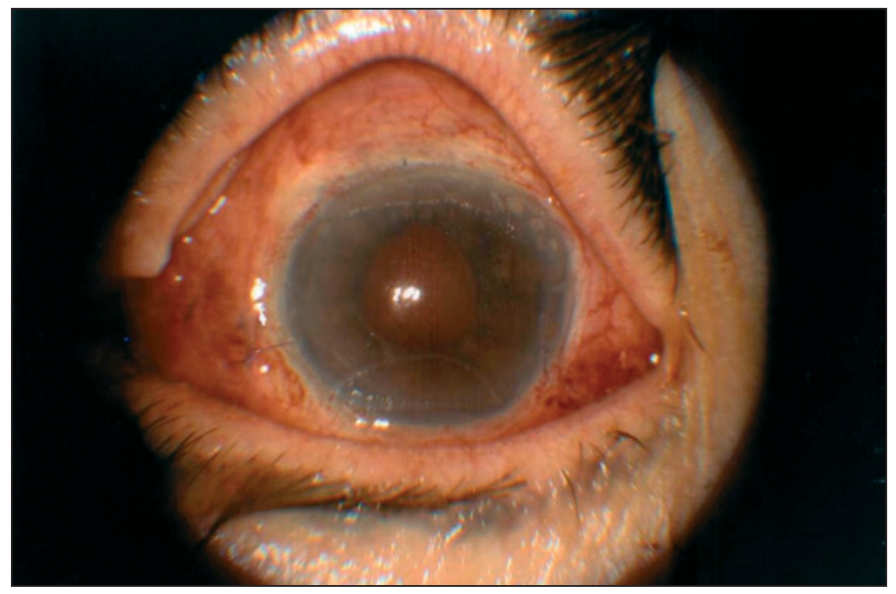

Figure 1 - First postop day. Explantation of the intraocular lens and removal of the lens capsule. cular lens implantation in the right eye (OD). The procedure was performed by the surgeon of the previous case two months afterwards. The patient's medical history disclosed no remarkable diseases. His BCVA in the right eye was 20/40, and he had a low-grade anterior chamber reaction. The vitreous was clear, and the retina was normal. Treatment was started with topical prednisolone and atropine with clinical improvement, but without complete resolution of the inflammatory reaction. Eleven months later, the patient complained of visual loss, pain and redness in his right eye. His BCVA in OD was hand movement $20 \mathrm{~cm}$. There was a severe anterior chamber inflammatory reaction (4+) with fibrin formation, keratic precipitates, and posterior capsule opacity. Ophthalmoscopically, retinal details were not visible. We performed vitrectomy with explantation of the intraocular lens and removal of the lens capsule. Vancomycin and ceftazidime were injected in the vitreous cavity. After surgery, the inflammation was controlled and did not recur. Cultures of the vitreous grew A. xylosoxidans (Figure 2). The patient‘s BCVA was 20/30.

\section{DISCUSSION}

There are few reports of chronic postoperative endophthalmitis caused by A. xylosoxidans ${ }^{(3-8)}$. Bacteria of the genus Alcaligenes are non-fermenting, gram-negative bacilli found in soil and water. They grow well in standard blood and MacConkey agar.

Contaminated irrigating solutions used during ocular surgery may have been the source of the infection because A. xylosoxidans is a common fluid contaminant ${ }^{(6)}$. In our patients, the source of the infection is unknown. Recalling that both cases were performed by the same surgeon suggests a common source of infection. In some of the reported

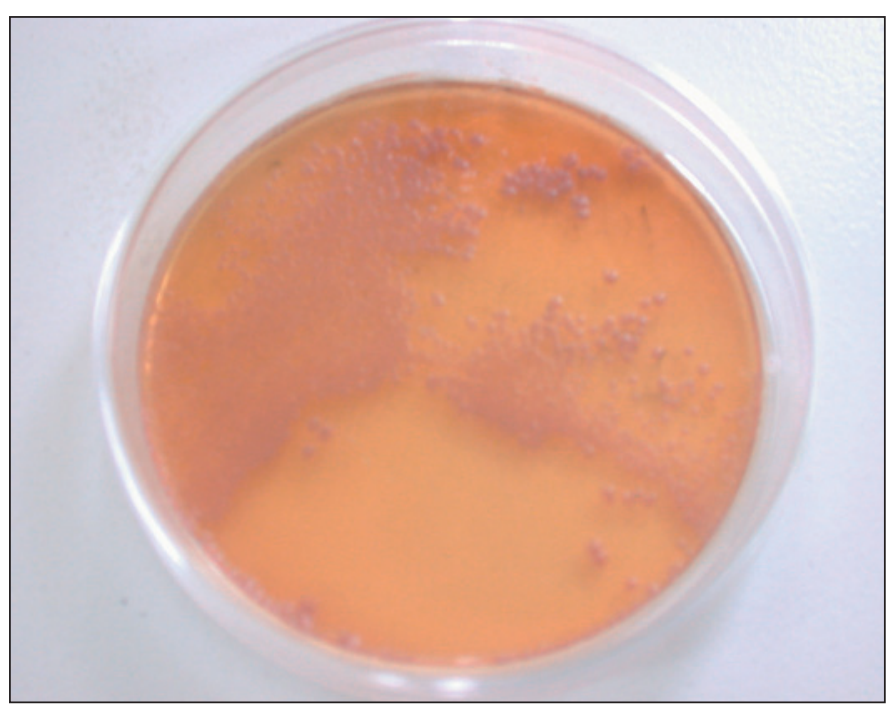

Figure 2 - Agar MacConkey culture shows pink colonies of gramnegative rods. Identification by API-20 and VITEK System was Alcaligenes xylosoxidans spp. xylosoxidans. 
cases of A. xylosoxidans endophthalmitis. Injections of antibiotics were sufficient to treat the infection.

A. xylosoxydans endophthalmitis should be considered a possible cause of chronic low-grade endophthalmitis after cataract surgery. Successful intervention may require not only intraocular antibiotics, but also complete vitrectomy with intraocular lens and capsule removal to eradicate the infection. In these cases, there was no antibiotic prophylaxis and thus it should be expected that implementation of the new guides for antibiotic prophylaxis can reduce this kind of infection after cataract surgery.

\section{RESUMO}

Relatamos dois casos de endoftalmite pós-operatória causada por Alcaligenes xylosoxidans. Uma mulher de 78 anos de idade e saúde geral boa desenvolveu endoftalmite por $A$. xylosoxidans um mês após ser submetida a facoemulsificação com implante de lente intra-ocular de câmara posterior, sem complicações. A cirurgia foi realizada no olho esquerdo em outra instituição. A remoção da lente e da cápsula intra-ocular foi realizada em consequiência da inflamação recorrente após vitrectomia e injeções intravítreas de antibiótico. Seu filho, de 55 anos, desenvolveu endoftalmite por A. xylosoxidans, no olho esquerdo, dois meses após facoemulsificação com implante de lente intra-ocular de câmara posterior (realizada também pelo mesmo cirurgião). Foi necessária também realização de vitrectomia com remoção da lente intra-ocular e da cápsula posterior em função da doença persistente. A. xylosoxidans pode causar a endoftalmite crônica, branda e progres- siva após a extração da catarata e é freqüentemente resistente à terapia antibiótica. Este tipo de caso é raro. De acordo com nosso conhecimento, existem apenas sete casos relatados previamente.

Descritores: Alcalígenes/isolamento \& purificação; Extração de catarata/efeitos adversos; Endoftalmite/microbiologia; Infecções oculares bacterianas/microbiologia; Implante de lente intra-ocular; Reoperação; Vitrectomia; Corpo vítreo / microbiologia; Adulto; Idoso; Feminino; Masculino; Relatos de casos [tipo de publicação]

\section{REFERENCES}

1. Meisler DM, Palestine AD, Vastine DW, Demartini DR, Murphy BF, Reinhart WJ, et al. Chronic Propionibacterium endophthalmitis after extracapsular cataract extraction and intraocular lens implantation. Am J Ophthalmol. 1986;102(6):733-9.

2. Soriano ES, Nishi M. Endophthalmitis: incidence and prevention. Curr Opin Ophthalmol. 2005;16(1):65-70.

3. Ficker L, Meredith TA, Wilson LA, Kaplan HJ, Kozarsky AM. Chronic bacterial endophthalmitis. Am J Ophthalmol. 1987;103(6):745-8.

4. Aaberg TM Jr, Rubsamen PE, Joondeph BC, Flynn HW Jr. Chronic postoperative gram-negative endophthalmitis. Retina. 1997;17(3):260-2.

5. Swart J, Völker-Dieben HJ, Reichert-Thoen JW. Alcaligenes xylosoxidans endophthalmitis 8 months after cataract extraction. Am J Ophthalmol. 1999; 127(3):345-6.

6. Rahma MK, Holz ER. Alcaligenes xylosoxidans and Propionibacterium acnes postoperative endophthalmitis in a pseudophakic eye. Am J Ophthalmol. 2000;129(6):813-5

7. Weissgold DJ, Kirkpatrick B, Iverson M. Acute postoperative Alcaligenes xylosoxidans endophthalmitis. Retina. 2003;23(4):578-80.

8. Uy HS, Matias R, de la Cruz F, Natividad F. Achromobacter xylosoxidans endophthalmitis diagnosed by polymerase chain reaction and gene sequencing. Ocul Immunol Inflamm. 2005;13(6):463-7.

\title{
XVI Congresso Norte-Nordeste de Oftalmologia

\author{
INFORMAÇÕES \\ Tel.: (91) 3230-5010 ou 3230-1622 \\ email: atualeventos@veloxmail.com.br \\ home-page: www.nortenordeste2008.com.br
}

